\title{
Alfred Schutz and Phenomenology of Religion: Explorations into Ambiguous Territory
}

\author{
Michael Staudigl ${ }^{1}$
}

Published online: 28 November 2017

(C) Springer Science+Business Media B.V. 2017

Alfred Schutz's socio-phenomenological account is paradigmatic for what has been termed a non- or post-foundational phenomenology of the social world (Steinbock 1995; Mensch 2001). The variety of related topics on which it has been applied over the last few decades is vast, covering a broad range of cultural, political, and technological (recently even socio-technological) phenomena. Applied phenomenology, thus viewed, is definitely flourishing and in a variety of instances helps us bridge the still yawning gap that threatens the interdisciplinary connectivity of research in the humanities and social sciences. Interestingly, however, religion, a topic that indeed calls for such broad, interdisciplinary inquiry and postfoundational ways of analysis, thus far has largely been absent from the invigorating prospects of Schutzian research.

At first glance, this absence might appear astonishing, but it is not unintelligible. And indeed, given Schutz's overall focus on the constitutive patterns of the "natural attitude" and the relevant structures of the "everyday life-world," as he prefers to call it, the fact that religion is not dealt with explicitly in his oeuvre, might appear intelligible. At least from some traditional phenomenological perspectives, religion is frequently conceptualized with regard to experiences of the extraordinary, the "excess," or the "wholly other," etc. Thus viewed in terms of what Schutz calls a kind of "big transcendence," its analysis is relegated either to the realm of the subjective (esp. feelings and emotive responses), to the domain of the theological ("revelation"), or to the question of "limit-phenomena" in need of being symbolically integrated into the general socio-logics of the life-world. Thus the dilemma of any "phenomenology of religion": whereas the focus on the "subjective side" often seems to betray a religious phenomenology (see Janicaud 2000), the

Michael Staudigl

michael.staudigl@univie.ac.at

1 Department of Philosophy, University of Vienna, Universitätsstraße 7 (NIG), 1010 Vienna, Austria 
heavy emphasis on the concrete articulation of religion's irreducible alterity in the last analysis all too quickly gets relegated to the level of social-theoretical explication. Without a doubt, religion, in its capacity to overcome and refigure the ordinary exhibits a major force that impacts the process of societal integration-but it is exactly this problem that has been tackled predominantly in functional accounts of religion (from Durkheim to Luckmann et al.). These kinds of functional accounts, however, tend to focus religion in terms of its analytic power to explain society yet largely refrain from confronting the very phenomenon of religion as such.

Why, thus viewed, would it appear astonishing to us that Schutz has not dealt with religion head on? It is astonishing since his works indeed seem to offer a comprehensive framework that could be used to elaborate an integrative account of religion; one that falls prey neither to functionalism and subjectivism, nor to any substantialist assumptions about the phenomenon at stake. ${ }^{1}$ Schutz, however, has only on a very few occasions mentioned the phenomenon of religion. In doing so in quite specific contexts he has, however, left us valuable guiding threads as to how to proceed and develop a respective socio-phenomenological account. The concepts that are of paramount importance in these contexts are his account of "multiple realities," as well as his related theory of "symbols," which allows for communication between such "realities". As is well known, Schutz strongly emphasized the role of so-called "multiple realities" as being part and parcel to his overall account of the life-world. It is explicitly in this context that religion also is mentioned as one among them.

Generally viewed, Schutz's theoretical take on these "subuniversa," "multiple realities," or "finite provinces of meaning" (to use his preferred title) focuses their meaningful constitution and cognitive integrity. He does not understand them as ontological features but rather conceives of them in terms of the internally coherent experiential attitudes or "cognitive styles" (including habitualized forms of interaction, typical patterns of self-experience, and forms of sociality, etc.) around which they revolve. As to his basic assumption, all "provinces of meaning" are dependent upon "everydayness" as their irreducible "hub". Put differently, for Schutz the everyday life-world is the "paramount reality" (1962: 226) of our very being and is formative of the ways it relates to a variety of our different "realities". For him the life-world is an always already socially derived (that is, pre-interpreted and sanctioned) world, revolving around a pre-given web of relevance-structures and a typified "stock of knowledge" that together afford us the capacities to practically come to terms with it. As Schutz furthermore contends, this world's major meaning-generating patterns concern the basic experience of our "fundamental anxiety" and the so-called "pragmatic motive" it entails. Put differently,

\footnotetext{
1 This critical account simply reiterates a selection of problematic methodological accounts in the study of religion nominated by Riesebrodt (2007). This author opts for an action-theoretical account to assure a both generic and comparatively qualified confrontation with the phenomenon of religion, a theoretical option that appears promising but unfortunately remains quite "disembodied," hence directly calling for phenomenological concretization. Schutz' account, as presented here, seems to offer vast potentials for such an undertaking, even if the acknowledged role of the "lived body" remains underdetermined in his thought. As for the task of elaborating a phenomenological theory of religion, I would thus call for a Schutzian framework that is further extended by including contemporary discussions in the phenomenology of embodiment and inter-corporeality.
} 
"since I know that I will die and I fear to die" (Schutz 1962: 228) my actions are guided by this "pragmatic motive": that is, the "primordial anticipation" that it is necessary to come to terms with the world by gearing into it, transforming it respectively, while always-due to our finitude-irreducibly being influenced by it.

Viewed against this backdrop, the importance of other "finite provinces of meaning" - e.g., the world of phantasy, scientific theory, play, or religion-seems to open onto a twofold set of possibilities: either it may consist in the opportunity to provide men with a kind of "time-out" (as Ayaß claims in this issue) from the pressing requirements of pragmatic coping with the everyday life-world; or it may consist in offering a sort of "resistance" (as we later will see Barber claims) to the meaning-generating principle of "pragmatic motivation". ${ }^{2}$ Whereas the option of taking "time-outs" might easily fold back into the pragmatics of everydayness, equipping it with a rhythmic surplus value of respite and relief, the motivational force of experiencing "resistance" seems to have a deeper impact: since provinces of meaning are distinguished by the fact that they embody a different "cognitive style" of experiencing, taking them can indeed help one to transcend the solidified (perhaps petrified) meaning-structures of everyday existence in which one mostly lives without reflecting upon it. Consequently, the liberating and sometimes indeed revelatory capacity to "break free" from the foundational logics of the "pragmatic motive" may have a variety of effects: (a) first and foremost, it can help one to "see through" (Schutz 1962: 257; see Augustine 1991: 184, book X: vi. (9); see Rom $1: 20)$ the socially derived interpretations pertaining to the pragmatics of everydayness; (b) it can consequently help one to transform topically limiting relevances into volitional ones; and, (c) it may motivate one to join efforts with others to collectively undermine the effective-be it self-assuring, alienating or oppressivesocietal function of pragmatic mastery going awry.

However adequate this description initially may seem, we also need to reflect upon the kind of "resistance" that the "religious finite province of meaning" communicates, for it does more than momentarily oppose (and sometimes overtly contradict) the general (socio)logic of everydayness. It moreover calls for a kind of responsive action that is able to meaningfully articulate this resistance and socially institute its capacities to "see through" the proclivities and relevances of everydayness in the everyday life-world. Its ultimate aim would be to expose it in a different light, namely in the liberating light of the "holy," of "transcendence,"

\footnotetext{
${ }^{2}$ We should be aware, of course, that the "verticality" (Steinbock 2007) of religious experience that this concept epitomizes, embodies but one specific kind of "resistance". Similar kinds of "resistance" that can motivate one to escape the reign of average "pragmatic orientation" can also consist in the imposition of an extraordinary intersubjective claim upon the ego agens (as in the case of the ethical encounter) or in the sublime experience of an overwhelming corporeal immensity (as in the case of the sublimity of the ecological). While the vexed question concerning especially the in/distinction between the ethical and the religious, which has haunted a whole tradition in philosophy, need not concern us here, I would still argue that it loses most of its acuity if we put it in the framework of Schutz's thought. Ethics, in the most basic sense of an "ethos in statu nascendi," has its birthplace definitely in the everyday life-world, developing in an "everyday morality" (Waldenfels 2013); religion, on the other hand, is a much more complex phenomenon that is dependent upon the interplay between everydayness and its reworking in imagination, and involves a relationship to both the ethical and the ecological, as pertinent discussions concerning both an "ethical religion" and "pantheism" clearly indicate.
} 
of the "absolute person," of "absolute affection," or however it may be called. From a decidedly Schutzian point of view, the truly interesting thing about "religion" hence is not about "religious truth-claims" and their potential confrontation at the threshold of reason (and be it in its "discursivized" form). Schutz, if he had embarked upon a closer analysis of this phenomenon, likely would rather have focused on the specific "cognitive style" that distinguishes the "religious finite province of meaning," especially on the specific "religious epoché" that it entails. Religion, in the context of this epoché, is not at all about the existence or non-existence of its assumed other-worldly referent; it is not about "ontological claims" concerning a "religious premise"; it rather concerns the intrinsic intelligibility of faith and spiritual practices that allow one to see oneself, one's world, and one's others from a truly different, that is, transcending viewpoint. It is about the constitution and symbolic institution (be it via unique boundaryphenomena such as shock or awe, or through recurrent symbolic practices such as initiation rites or liturgies) of an "appresentative mindset" (Barber 2017) that becomes capable of "seeing through" its everydayness. As for the various religious traditions we know, this might be cast in terms of an uneconomic logic of the gift, be it the revelation of a "wholly other," the Christian doctrine of salvation, the Islamic concept of Ar-Rahman resp. Ar-Rahim (a specific kind of mercy), or the Buddhist notion of dharma, etc. It is in this context that a truly Schutzian account of religion consequently would need to describe systematically the various ways such "seeing through" (frequently referred to as "second birth" in various traditions) can be motivated, how it affects and possibly transforms the subject's "cognitive style," and thus creates a "religious finite province of meaning" on its own. Schutz's account of "finite provinces of meaning" thus can be used to confront fruitfully and explore the phenomenon of religion. Its major tasks would consist: (1) in demarcating the specific experiential style (and correlative "appresentative mindset") that the "religious finite province of meaning" entails, including its specific "epoché," as well as its major forms of "tension of consciousness," spontaneity, sociality, patterns of time- and self-experience"; (2) in delineating the variety of ways that this "province of meaning" is related to and interacts with the everyday life-world (and possibly also other "subuniversa"), including a focus on narratives/media of access, socio-cultural/political rules of transition, and lived practices of institution; and (3) in demonstrating that a focus on the interaction or exchange between the "finite religious province of meaning" and the pragmatics of the everyday life-world (that the former holds to "see through") also can help us shed some light on the yet to be thought intertwining of religion with its "other"be it the vexed relationship of religion and technology that is paramount in the current "return of the religious" or the disconcerting correlation that seems to bind religion and violence so closely together today. Put differently, a central, pressing question concerns how a religion's "transcending force" can be instituted symbolically in the everyday life-world (e.g., by way of what Schutz calls "enclaves") in order to secure its liberating power, and this indeed touches upon the most relevant issues that are discussed in religious theory and philosophy of religion today. 
The contributions to this special issue set out to elaborate on these yet unplumbed potentials of Schutz's thought to confront religion. The collected papers took up the task not only to assess the conceptual and methodological resources of Schutz's phenomenology, but also did so with the intent to explore concretely the realities of "lived religion" from an applied, socio-phenomenological viewpoint. Regarded in detail, the contributions fathom explicitly the potentials of Schutz's theory of "multiple realities," his account of the symbol, and his conception of "relevance" to (1) confront and describe a specifically "religious finite province of meaning," (2) study specific phenomena of religious practice, (3) productively think through religion's critical interrelation with secular life-worlds and the changing realities of so-called "post-secularism," and, (4) address the topical correlation of religion and violence from a specific point of view. It now is necessary to turn from this brief, systematic, and somewhat abstract outline to the more concrete applications found in the contributions of the authors included in this special issue.

In his incipient contribution, Michael Barber (St. Louis) took up the overall program with utmost accuracy. His paper provides the reader with a basic yet comprehensive outline for studying religion in Schutz's terms of a "religious finite province of meaning". The author clearly emphasizes the specific kind of "resistance" that the taking of the "religious epoché" implies. Furthermore he delineates several generic specificities pertaining to the "religious province of meaning" by comparing it with the "literary sphere of meaning" and the province of "theoretical contemplation". Barber's focus hereby rests on the specific ways the eidetic features of everyday existence (especially the way it revolves around the pragmatic mastery of the world by the ego agens), its experiential habitus, and typified way of dealing with others, are modified and transformed into a more or less coherent "religious finite province of meaning". He goes on to inquire how this "province of meaning" can be accessed by way of a specific "religious epoché," and asks how the resistant and hence critical "intelligibility" of religion is in need of being built dialectically into everydayness and how it might be reconciled (or not) with this world's pragmatic infrastructure. ${ }^{3}$ Indicating this necessity, the article stresses the potential of such a religious finite province of meaning to "counterbalance the world of working" and the pragmatic imperatives around which it revolves. Whether or not the "dialectical interplay" invoked by Barber necessarily involves violence or rather remains an "open dialectic" are questions that by definition remained beyond the scope of his investigation. Inasmuch as the interested reader cannot but feels urged to pose such questions, this contribution undoubtedly demonstrates the scope and the potentials of a socio-phenomenological account of religion.

Ruth Ayaß (formerly Klagenfurt, now Bielefeld), also takes the concept of "finite provinces of meaning" as her starting point. Ayaß, however, besides the interest in

\footnotetext{
3 It should be mentioned that Barber (2017) has in the meantime published a whole book on this topic, wherein he applies in much more depth and concreteness the basic conceptual framework he has outlined in this article. Of special interest is his effort there to shed light on the specific character of religion by confronting it with the "humorous province of meaning," a confrontation that provides the reader with many important insights concerning the liberating power of both as well as the ways in which they can interact and reciprocally impact each other in a positive way.
} 
also distinguishing the generic features of such provinces, pursues a different intention. Her focus ultimately consists of bringing this concept to bear on the question concerning the various "realnesses" of such provinces, thus reading the concept of the "after-world" through a Schutzian lens. She proposes to consider conceptions of "the hereafter" and "paradise" in terms of "ultimate provinces of meaning". Through her interpretation of "On multiple realities" Ayaß focuses strongly on the "pragmatics of finite provinces of meaning," or the "existential problems" they entail; that is, on the "ways they incorporate themselves into, and have an effect on everyday life". The questions as to how humankind is capable of "commuting" between them, how these problems are "embedded" in everydayness, and how they can be dealt with by "everyday methods" hence are of paramount interest. This involves the related insight that the variety of attempts pragmatically to secure access to the "religious finite province of meaning" in the everyday lifeworld indeed "generates social structures and material facts [...] which in turn shape and channel the access"; that is, indeed create sacred times, places, etc. Following this line of thought, Ayaß finally argues that this kind of "border traffic" helps explain why specific attitudes related to conceptions of the hereafter or paradise can in turn be exported from these "realities" back to the everyday lifeworld-and may indeed influence them in a constitutive way. As the example of Calvinist ethics and the doctrine of predestination shows, the "religious finite province of meaning" and the world of everydayness indeed influence each other, sometimes to the extent that attitudes coined in another "reality" have an enduring and indeed transformative impact on everyday existence.

Mar Griera's (Barcelona) paper offers a creative application of Schutzian concepts on the study of so-called "new spiritual imaginaries". ${ }^{4}$ Her major interest is in the practice of Yoga in the context of penitentiary settings in which she has done ethnographic research. In this article, she focuses on the role and potential of Yoga as a-both bodily and spiritual-technique to enter another province of meaning, to reflectively experience "transcendence," and finally to embark onto a "spiritual journey" that might lead practitioners into a productive process of personal transformation. To demonstrate the feasibility and coherence of these hypotheses, Griera applies Schutz's conception of the "finite province of meaning" and broadens his notion of "the stock of knowledge" also to include spiritual knowledge. In the last analysis, Griera succeeds in demonstrating that the practice of Yoga in penitentiary settings indeed entails a variety of recreative and perhaps even healing potentials not only on the physical level but also in terms of cognitive transformation. As she contends, this may help breach a doorway into a different "reality" that can enable someone to see her own "true self". This process indeed, as the author argues, can be understood in terms of a "holistic spirituality" that binds the practitioner with an intersubjectively sustained way of experiencing transcendence. On the one hand, this whole argument attests to an experience that clearly mirrors the fundamental changes we are witnessing in our Western "post-

\footnotetext{
${ }^{4}$ Unfortunately, due to an organizational mistake, Griera's paper has already been published in a former issue of Human Studies (40/1, 2017: 77-100). However, as it has been conceived as a part of this special issue, we include its presentation in this introduction.
} 
secular" understanding of "religion" today; one the other hand, such a post-secular society frequently has been devalued as the mere opening of a "commodity market of transcendencies". Whether taken as a "sociological fact" or depreciated (philosophical) artifact, the phenomenon as such clearly demands further analysis and this article indeed makes us sensitive to this desideratum.

Hoshikawa (Tokyo) and Staudigl (Vienna) have contributed a paper that attempts to provide a socio-phenomenological analysis of a concrete religious phenomenon-(Christian) prayer. Prayer indeed frequently is taken as a kind of touchstone for the study of religion in general and has sometimes even been purported to represent the religious phenomenon par excellence (Chrétien for example). Although the authors do not engage this question at length, they seek to creatively apply Schutz's framework for the sake of studying its major phenomenal contours. However, since prayer basically involves both consciousness and language as constitutive patterns, they chose to confront the Schutzian account with perspectives from linguistic philosophy, namely Austin, Evans and Wittgenstein. Delineating the phenomenological contours of a "religious finite province of meaning" that is articulated in more depth in the other papers assembled here, they start from the phenomenological assessment that prayer works as a kind of "enclave" in Schutz's sense. Put differently, prayer is presented as a means of entering the "religious finite province of meaning" from within everydayness. Hoshikawa and Staudigl proceed by interpreting this transition in terms of a "leap": prayer, accordingly is conceived in terms of its capacity to qualitatively change the direction of the stream of consciousness and to reactivate a polythetic wealth of meaningful implications at the very heart of experience that is silenced in the quasiontological homogeneity of everydayness. Understood as a kind of "religious epoché," it is presented to (re)establish an "attentional attitude" that enables one to "commute" to this other "reality". The fact that Schutz himself relates this change in "attentional attitude" to the question of symbolic expression, clearly indicates the special role language plays in this context. Adopting positions from linguistic philosophy, the authors accordingly demonstrate that prayer revolves around "selfinvolving" or "performative" speech acts. The central role of the one who prays involves the recovery of a non-propositional relationship with the overall "system" of the respective "language-game," thus allowing those of us who pray to confront the "groundlessness of our believing" and gain insight into the primacy of "acting" (Wittgenstein). While this might be interpreted as resulting in the immanence of playing an "in-game," the authors finally defend the idea that the problem is not one of communication (of finding a "formula of transformation," in Schutz's terms) between different "realities," but rather one that concerns the capacity of an individual to re-late to itself in the disturbing light of another.

Ilja Srubar's (Erlangen) contribution focuses on the topical but difficult relationship between religion and violence. It is a genuine attempt to bring Schutz's pragmatic theory of the life-world to bear on a problem that is of broadest importance for recent social theory and philosophy of religion. Srubar here critically confronts the irreducible ambivalence that frequently has been taken to be part and parcel of religion's stance toward violence. As he argues, we are in deep need to deconstruct the widespread theoretical habit to either regard violence as a 
"structural attribute" of religion, or otherwise consider it as some "temporarily misdirected behavior" accidentally motivated by the narrative semantics of some particular religious tradition. In order to avoid any kind of such reductionism in explication, Srubar proposes to analyze critically the relationship between religion and violence on three different but interrelated levels. As for the first and most basic level, he contends that violence should be understood as a constitutive pattern in the various forms of one's "communication with the sacred," occurring, e.g., in epiphanies and revelations. Being first experienced on the most basic level of one's bodily exposure to the overwhelming power of the "transcendent," violence in turn is instituted as a "medium of a-semiotic communication" with the "sacred". On a second level, Srubar argues that violence is present in the religiously shaped divisions of the life-world, that is, in terms of social inclusion and exclusion. It is on that level that distinctions like purity/danger are translated into hetero-normative dichotomies like orthodoxy/heterodoxy, or orthodoxy/heresy. In this context violence appears as a kind of enforcement of "truth claims" projected onto the experience of the "sacred". Finally, violence is both worked into and critically reflected in the "narrative semantics" of religious systems of knowledge: it is on this level that violence, generally understood as an a-semiotic medium of meaningful communication in religious systems of knowledge, is subjected to the authorities of social control and interpretation. However, as the author argues with reference to conceptions of theodicy (as one example), the mediation of violence on this level remains inherently precarious, frequently legitimizing different forms of counter-violence. As the author concludes, this precariousness even survives in secular modernity inasmuch as it remains parasitic upon both the "narrative semantics" of religions as well as on the "originally activating power" dealt with in religious systems of knowledge. This may not only be demonstrated with regard to the so-called "political religions," as Srubar does; it also may find evidence in the context of "post-secular" political theory and the way it bends back onto a "politics of the unconditional" (Staudigl 2014).

Two review essays complete this special issue. In the first, Jason Alvis (Vienna) critically engages with Anthony J. Steinbock's groundbreaking phenomenological study Phenomenology and Mysticism: The verticality of religious experience (2007), unfolding both its unprecedented phenomenological potentials as well as discussing its limits. In another review, Jan Frei provides an examination of Michael Reder's Religion in säkularer Gesellschaft. Über die neue Aufmerksamkeit für Religion in der politischen Philosophie (2013), offering an informative oversight of its enormous thematic scope and various hypotheses regarding the changing role of religion in our contemporary everyday life-world - thus addressing questions that relate back to the general context that has offered a basic motivation for putting together this special issue.

Acknowledgements I would like to thank Martin Endreß for accepting my proposal to edit this special issue of Human Studies, for his careful guidance as we proceeded through the review processes, revisions, and final preparations. My thanks extend to Jason W. Alvis for his generous help in correcting the English and overall support in editing this volume. This Special Issue was edited with the generous support of two research grants from the Austrian Science Fund (FWF): it was conceived and started in the framework of the project 'Religion beyond myth and Enlightenment' (FWF P 23255), and was concluded in another 
project entitled 'Secularism and its Discontents. Toward a Phenomenology of Religious Violence' (P 29599).

\section{References}

Augustine (1991). Confessions (H. Chadwick, Trans.). Oxford: Oxford University Press.

Barber, M. D. (2017). Religion and humor as emancipating provinces of meaning. Cham: Springer.

Janicaud, D. (2000). The theological turn of French phenomenology. In D. Janicaud, J.-F. Courtine, J.-L. Chrétien, M. Henry, J.-L. Marion, \& P. Ricœur (Eds.), Phenomenology and the "Theological Turn" (B. G. Prusak, Trans.) (pp. 16-103). New York: Fordham University Press.

Mensch, J. (2001). Postfoundational phenomenology. Husserlian reflections on presence and embodiment. University Park: Pennsylvania State University Press.

Reder, M. (2013). Religion in säkularer Gesellschaft. Über die neue Aufmerksamkeit für Religion in der politischen Philosophie. Alber: Freiburg \& Munich.

Riesebrodt, M. (2007). The promise of salvation. A theory of religion. (S. Rendall, Trans.). Chicago: The University of Chicago Press.

Schutz, A. (1962). On multiple realities. In M. Natanson (Ed.), Collected papers, Vol. 1. The problem of social reality (pp. 207-259). The Hague: Nijhoff.

Staudigl, M. (2014). Unbedingte Ansprüche im Widerstreit. Die Zerstörung der Buddhas von Bamiyan als Fallbeispiel. In B. Liebsch, \& M. Staudigl (Eds.), Bedingungslos? Zum Gewaltpotenzial unbedingter Ansprüche im Kontext politischer Theorie (pp. 275-298). Baden-Baden: Nomos.

Steinbock, A. J. (1995). Home and beyond. Generative phenomenology after Husserl. Evanston: Northwestern University Press.

Steinbock, A. J. (2007). Phenomenology and mysticism. The verticality of religious experience. Bloomington: Indiana University Press.

Waldenfels, B. (2013). Everyday morality. Questions with and for Alfred Schutz. In M. Staudigl (Ed.), Schutzian phenomenology and hermeneutic traditions (pp. 181-198). Dordrecht: Springer. 